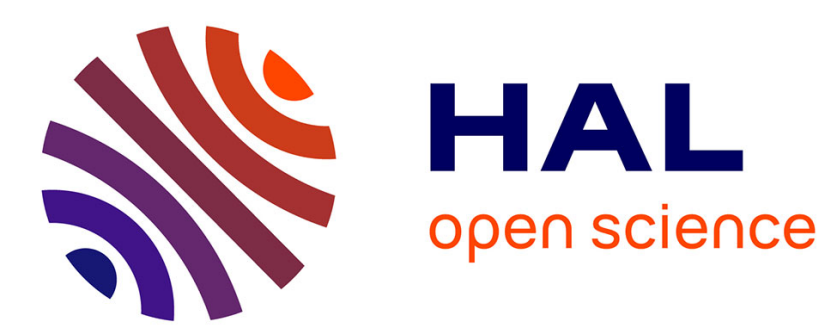

\title{
PLASMA DEPOSITION OF SILICON NITRIDE
}

\author{
C. Fakih, R. Bes, B. Armas, D. Thenegal
}

\section{To cite this version:}

C. Fakih, R. Bes, B. Armas, D. Thenegal. PLASMA DEPOSITION OF SILICON NITRIDE. Journal de Physique IV Proceedings, 1991, 02 (C2), pp.C2-413-C2-420. 10.1051/jp4:1991250 . jpa-00249840

\section{HAL Id: jpa-00249840 https://hal.science/jpa-00249840}

Submitted on 1 Jan 1991

HAL is a multi-disciplinary open access archive for the deposit and dissemination of scientific research documents, whether they are published or not. The documents may come from teaching and research institutions in France or abroad, or from public or private research centers.
L'archive ouverte pluridisciplinaire HAL, est destinée au dépôt et à la diffusion de documents scientifiques de niveau recherche, publiés ou non, émanant des établissements d'enseignement et de recherche français ou étrangers, des laboratoires publics ou privés. 
Colloque C2, suppl. au Journal de Physique II, Vol. 1, septembre 1991

\title{
PLASMA DEPOSITION OF SILICON NITRIDE
}

\author{
C. FAKIH* R.S. BES*, B. ARMAS** and D. THENEGAL ${ }^{* *}$ \\ "Laboratoire de Génie Chimique, U.R.A 192 C.N.R.S, C/O \\ E.N.S.I.G.C, F-31078 Toulouse, France \\ * *Institut de science et de Génie des Matériaux et Procédés. \\ C.N.R.S, Odeillo, F-66120 Font Romeu, France
}

\begin{abstract}
This paper reports on the preparation and characterization of thin films of silicon nitride deposited on heated silicon substrates from $\mathrm{Si}\left(\mathrm{CH}_{3}\right)_{4}-\mathrm{NH}_{3}-\mathrm{H}_{2}$ mixtures activated at room temperature by an a.c. discharge at low frequency. The films were deposited at $800^{\circ} \mathrm{C}$. Deposition rate as well as refractive index were measured and several parameters were systematically varied, including deposition time $(1-3 \mathrm{~h})$, total gas flow rate, chamber pressure $(20-45$ $\mathrm{kPa})$, peak driving voltage $(8-12 \mathrm{kV})$ and frequency $(400-600 \mathrm{~Hz})$. The composition of the films was studied using transmission electron microscopy $\left(10^{6} \mathrm{~V}\right)$, Auger spectroscopy and infrared spectroscopy.
\end{abstract}

\section{1-INTRODUCTION}

In plasma CVD reactors, the substrates are generally immersed in the discharge and resistively heated $/ 1 /$. Using such a device, the discharge is produced in the gaseous reactant mixture which is maintained at low pressure (5-200Pa) under an r.f. plasma. Thus "silicon nitride" films (actually $S i_{x} \mathrm{~N}_{Y} \mathrm{H}_{z}$ ) are deposited at temperatures between 20 and $500^{\circ} \mathrm{C}$ from $\mathrm{SiH}_{4}-\mathrm{NH}_{3}-\mathrm{Ar}$ mixtures $/ 2 /$, at temperatures between 300 and $600^{\circ} \mathrm{C}$ from $\mathrm{SiH}_{4}-\mathrm{NH}_{3}-\mathrm{N}_{2}$ mixtures /3/ and recently at temperatures between 25 and $200^{\circ} \mathrm{C}$ from the reactant mixture $\mathrm{Si}\left(\mathrm{CH}_{3}\right)_{4}-\mathrm{NH}_{3} / 4 /$. Moreover, similar silicon nitride films have been deposited at room temperature using low frequency ( $50 \mathrm{~Hz}$ ) plasma CVD with $\mathrm{SiH}_{4}-\mathrm{N}_{2}$ mixtures at about $160 \mathrm{~Pa}$ total pressure $/ 5 /$.

Finally, as a matter of comparison, $\mathrm{Si}_{3} \mathrm{~N}_{4}$ can be deposited on graphite subtrates by low pressure (520-1320 Pa) pyrolysis of $\mathrm{Si}\left(\mathrm{CH}_{3}\right)_{4}$ $-\mathrm{NH}_{3}-\mathrm{H}_{2}$ mixtures in a hot wall reactor $\left(1000-1200^{\circ} \mathrm{C}\right) / 6 /$.

silicon nitride deposits made below a temperature of $500^{\circ} \mathrm{C}$ contain non-negligible quantities of hydrogen. On the other hand, fabrication of deposits above $1000^{\circ} \mathrm{C}$ can lead to undesirable reactions with the substrate.

Here, we describe a technique which enables the fabrication of hydrogen-free layers of silicon nitride at a temperature between 500 and $1000^{\circ} \mathrm{C}$.

\section{2-EXPERIMENTAL}

The film deposition equipment is shown schematically in Figure 1. The vertical reactor is a silica tube $620 \mathrm{~mm}$ high and $40 \mathrm{~mm}$ in diameter. The lower part of the reactor is the electronic activation zone where an a.c. discharge is produced in the gaseous reactant mixture. The high voltage discharge electrode is constituted by a 


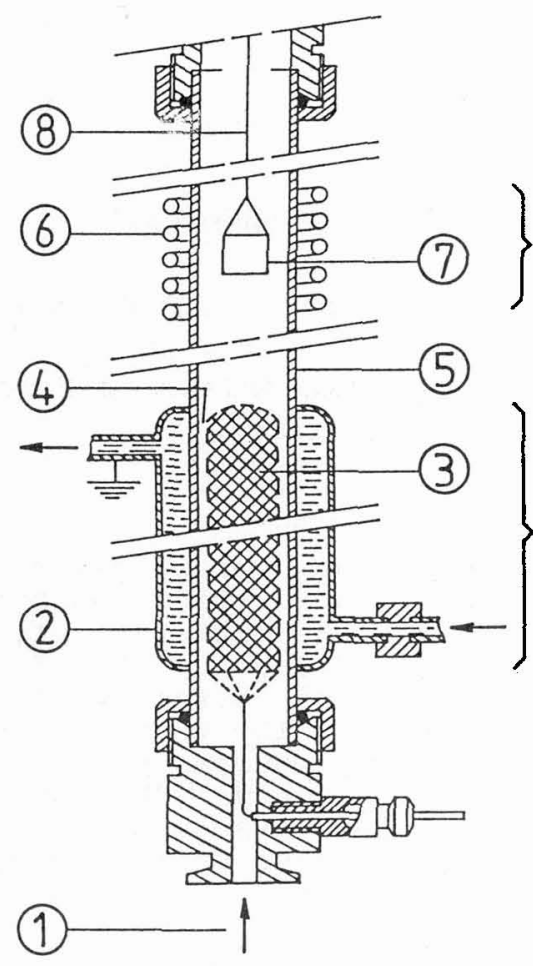

\section{ELECTRONIC ACTIVATION ZONE}

Fig. 1.- Film deposition apparatus. (1) gas inlet; (2) water jacket; (3) high voltage electrode ; (4) gaseous gap : (5) silica tube ; inductive coil ; (7) susceptor ; (8) molybdenum wire.

stainless steel cylindrical inner grid, the radius of which is very close (about $1 \mathrm{~mm}$ ) to the radius of the outer tube, acting as grounded electrode. The square mesh aperture of the grid $(112 \mu \mathrm{m})$ has been chosen to be about twice the Debye length /7/ in such a plasma. The outer tube is cooled directly with water from the laboratory supply. Electrically, the cold plasma zone presents a capacitive load to the power supply due to both the gaseous gap and the dielectric barrier present (Figure 2).

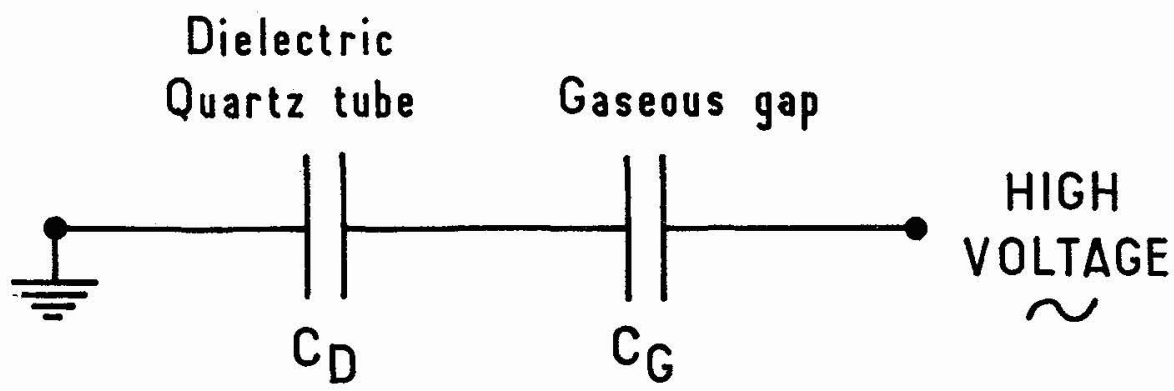

Fig.2.-Equivalent circuit: $1 / \mathrm{C}_{\mathrm{T}}=1 / \mathrm{C}_{\mathrm{G}}+1 / \mathrm{C}_{\mathrm{D}}$ 
The power and control circuit has been described previously /8/. The power $W$ dissipated in the gaseous gap can be calculated from the Manley expression /9/ :

$$
\mathrm{W}=4 \mathrm{f} \mathrm{C}_{\mathrm{D}} \mathrm{V}_{\mathrm{O}}\left(\mathrm{Vm}-\mathrm{C}_{\mathrm{D}} \mathrm{V}_{\mathrm{O}} / \mathrm{C}_{\mathrm{D}}-\mathrm{C}_{\mathrm{T}}\right) \quad(1)
$$

where $f$ is the frequency $(\mathrm{Hz}), \mathrm{C}_{\mathrm{D}}$ and $\mathrm{C}_{\mathrm{T}}$, the capacitances ( $F$ ) respectively of the dielectric barrier and of the plasma reactor, $V_{m}$. the peak driving voltage $(V)$ and $v_{0}$, the peak across the gaseous gap (V).

The upper part of the reactor is the thermal activation zone. The graphite susceptor of the silicon substrate $(6 \times 6 \mathrm{~mm})$ is sustained by a molybdenum wire within the central axis of the tube and heated by an inductive coil. The temperature of the susceptor is controlled and measured by an optical pyrometer.

Before any experiment, the reactor was evacuated to a pressure of about $10^{-1} \mathrm{~Pa}$. A mixture of tetramethyl silane (TMS), ammonia ( $\mathrm{NH}_{3}$ ) and hydrogen $\left(\mathrm{H}_{2}\right)$ was used for depositing thin films. Whisle the gaseous mixture was flowing into the reactor, the plasma was initiated until the suceptor temperature is adjusted.

Such a general film deposition equipment characterized mainly by successive use of electronic and thermal activations has been patented by our research team /10/. So only preliminary results will be presented in this paper in order to judge the ability of this novel technique to produce good quality thin films.

A Rudolph Research automatic ellipsometer $(\lambda=63280 \mathrm{~nm})$ was used to measure film thickness and index of refraction. The composition of the films was studied using AUGER electron spectroscopy (RIBER SIA 200), infrared spectroscopy (PERKIN-ELMER $1760 \mathrm{X}$ ) and electron energy loss spectroscopy (EELS) on the $1 \mathrm{MV}$ electron microscope from the CEMES CNRS, located in TOULOUSE.

\section{3-RESULTS AND DISCUSSION}

The experimental data show the influence of the following parameters on the deposition process: deposition time, total gas flow rate $Q$, reactor total pressure $P$, frequency and peak driving voltage. The substrate temperature was kept constant $\left(800^{\circ} \mathrm{C}\right)$.

\subsection{Deposition time}

The weight of the samples increases linearly with deposition time as shown in Figure 3 . This means that the reaction is carried out under

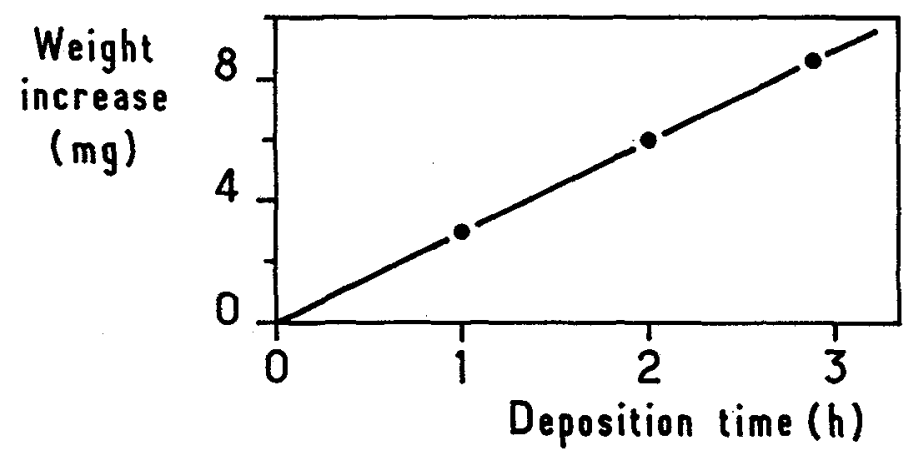

Fig.3.- Weight increase of the samples as a function of deposition time. $\mathrm{P}=38 \mathrm{kPa} ; \mathrm{Q}=160 \mathrm{~cm}^{3} \cdot \mathrm{min}^{-1} \mathrm{STP} ;\left(\% \mathrm{TMS}=9.37 ; \frac{8}{8} \mathrm{NH}_{3}=28.1 ; \frac{8}{8}\right.$ $\mathrm{H}_{2}=62.5$ ); $\mathrm{Vm}=12 \mathrm{kV} ; \mathrm{f}=500 \mathrm{~Hz}$. 
the steady state and that the deposition rate $r$ can be directly derived from the slope of the straight line.

\subsection{Total gas flow rate}

The influence of the total gas flow rate on the deposition rate and refractive index of the films is shown in Figure 4. The deposition

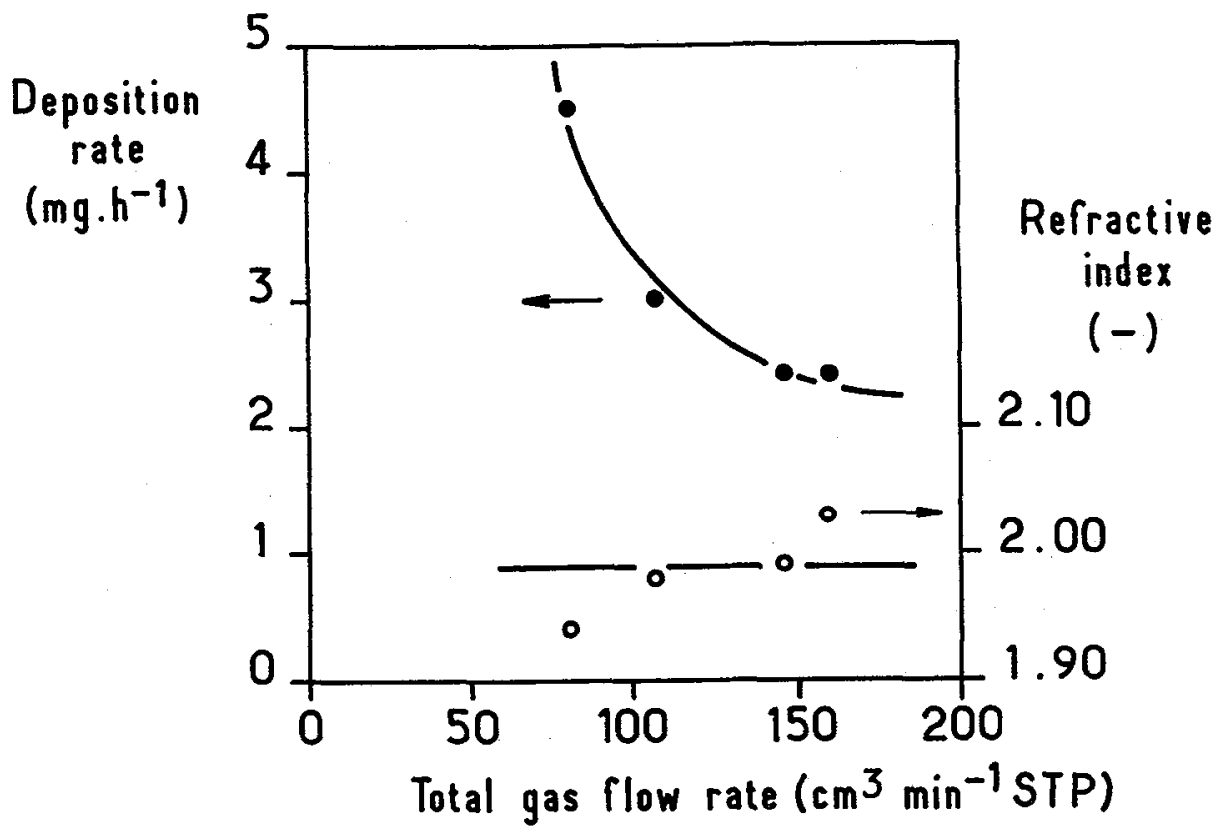

Fig.4.-Deposition rate and refractive index of the films as a function of the total gas flow rate ( 8 TMS $=9.37 ; 8 \mathrm{NH}_{3}=28.1 ;$; $8 \mathrm{H}_{2}=$ 62.5 ). $\mathrm{P}=34 \mathrm{kPa} ; \mathrm{Vm}=10 \mathrm{kV} ; \mathrm{f}=500 \mathrm{~Hz}$.

rate decreases with $Q$ while refractive index $\mathbf{n}$ is quite constant $(1.99 \pm 0.03)$. Such a value is very close to refractive index 2.0 of stoichiometric silicon nitride /5/. The influence of $Q$ on deposition rate $r$ agrees with the theory of chemical reactions induced by electrical discharges into a gas $/ 11 /, i . e . r$-a measure of the extent of transformation - is an increasing uniform function of Becker's parameter $\beta=W / Q . N / 12 /$ keeping in mind that here the power dissipated $W$ and the total gas concentration $N$ are constant.

\subsection{Total pressure}

Figure 5 shows the deposition rate and the refractive index of the films as a function of the reactor total pressure $P$. The same trend observed for the variations of $r$ and $n$ with the total pressure is in agreement with previous work /13/. Here as total pressure increases deposition rate and refractive index increase at first and then decrease. Existence of an optimal value for $P$ seems to be $a$ physical reality. Indeed assuming a Maxwellian distribution for the plasma electron energy and validity of Paschen's law $/ 14 /$ for the gaseous mixture, it may be concluded that the observed variation of the two deposition parameters results from an optimal value of the mean electron energy for the reactant gas dissociation $/ 11 /$, that is the preliminary step leading to deposition on the heated substrate. 


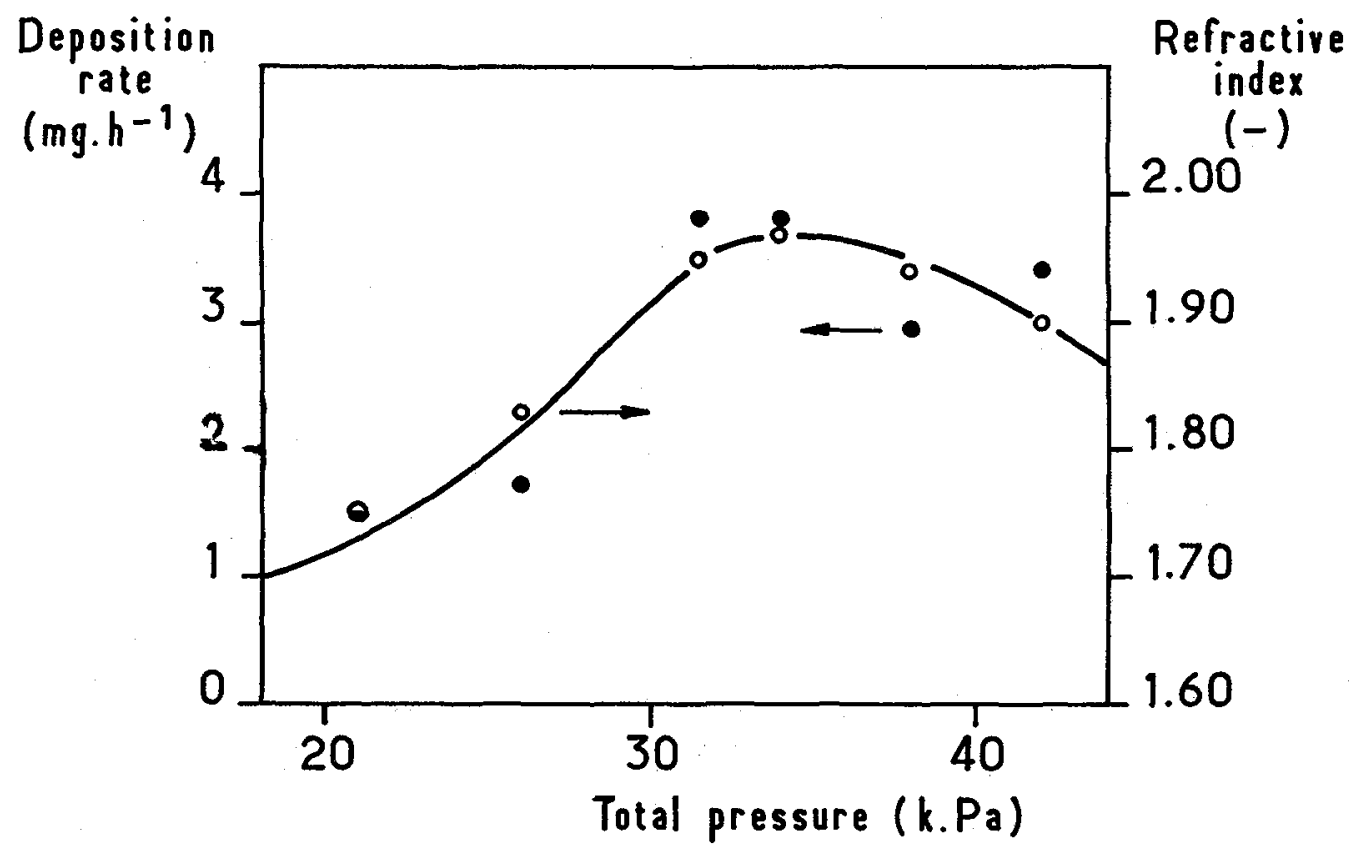

Fig.5.- Deposition rate and refractive index of the films as a function of the reactor total pressure. $Q=160 \mathrm{~cm}^{3} \cdot \mathrm{min}^{-1}$ STP; ( 8 TMS = $9.37 ;$ if $\mathrm{NH}_{3}=28.1 ;$ o, $\left.\mathrm{H}_{2}=62.5\right) ; \mathrm{Vm}=12 \mathrm{kV} ; f=500 \mathrm{~Hz}$.

\subsection{Frequency and peak driving voltage}

In these experiments composition of the gas mixture, total flow rate and total pressure were kept the same. According to equation 1 , in order to change the dissipated power, we can act either on frequency $f$ or peak driving voltage $\mathrm{Vm}$. Other parameters appearing in the equation, $C_{D}, C_{T}$ and $V_{0}$, are some constants that can be easily measured $/ 8 /$. So two series of experiments have been conducted by changing $f(400-600 \mathrm{~Hz})$ at $V m=12 \mathrm{kV}$ and by changing $\mathrm{Vm}(8-12 \mathrm{kV})$ at $f=500 \mathrm{~Hz}$. Figure 6 shows the deposition rate and the refractive index of the films as a function of dissipated power. As expected /11,12/ the deposition rate is an increasing uniform fuction of the power while refractive index is quite constant (1.95 0.03$)$. In fact as indicated earlier the physical parameter is Becker's parameter $\beta$, i.e. the delivered energy per reactant gas molecule. So in order to compare the different sets of experiments, Figure 7 shows the deposition rate and the refractive index of the films as a function of the ratio $W / Q$ ( $N$ being here a constant) calculated from Figures 4 and 6. As a matter of fact, we can conclude that effectively the deposition rate $r$ is an increasing uniform function of $W / Q$ while the refractive index is quite constant $(1.96 \pm 0.03)$. In the outline of the theory of chemical reactions induced by electrical discharges $/ 11,12 /$ such results can be explained by the fact that by working at a given value for the reduced electrical field $E / N$ (equal to $V_{0} / N . d$, $d$ being the electrodes spacing) the increase of $\mathrm{W} / \mathrm{Q}$ results only in an increase of the number of plasma electrons having an energy. As a result the given reactant gases dissociation is increased but the dissociation mode is the same and thus the nature of the deposit on the heated substrate is the same. 


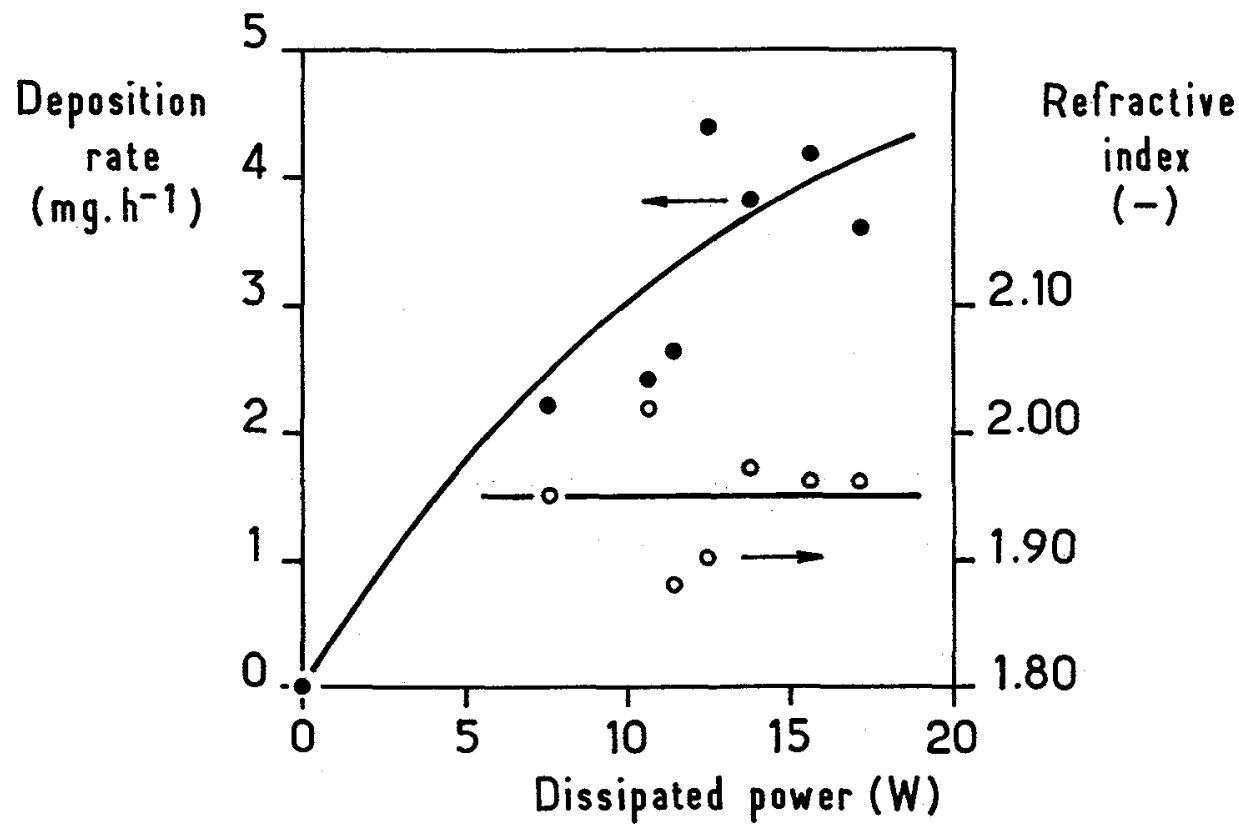

Fig.6.-Deposition rate and refractive index of the films as a function of the dissipated power. $Q=160 \mathrm{~cm}^{3} \cdot \mathrm{min}^{-1} \mathrm{STP} ;\left(\frac{8}{8} \mathrm{TMS}=9.37 ;\right.$; $\mathrm{NH}_{3}=$ $28.1 ;$ \& $\mathrm{H}_{2}=62.5 ; \mathrm{P}=34 \mathrm{kPa}$.

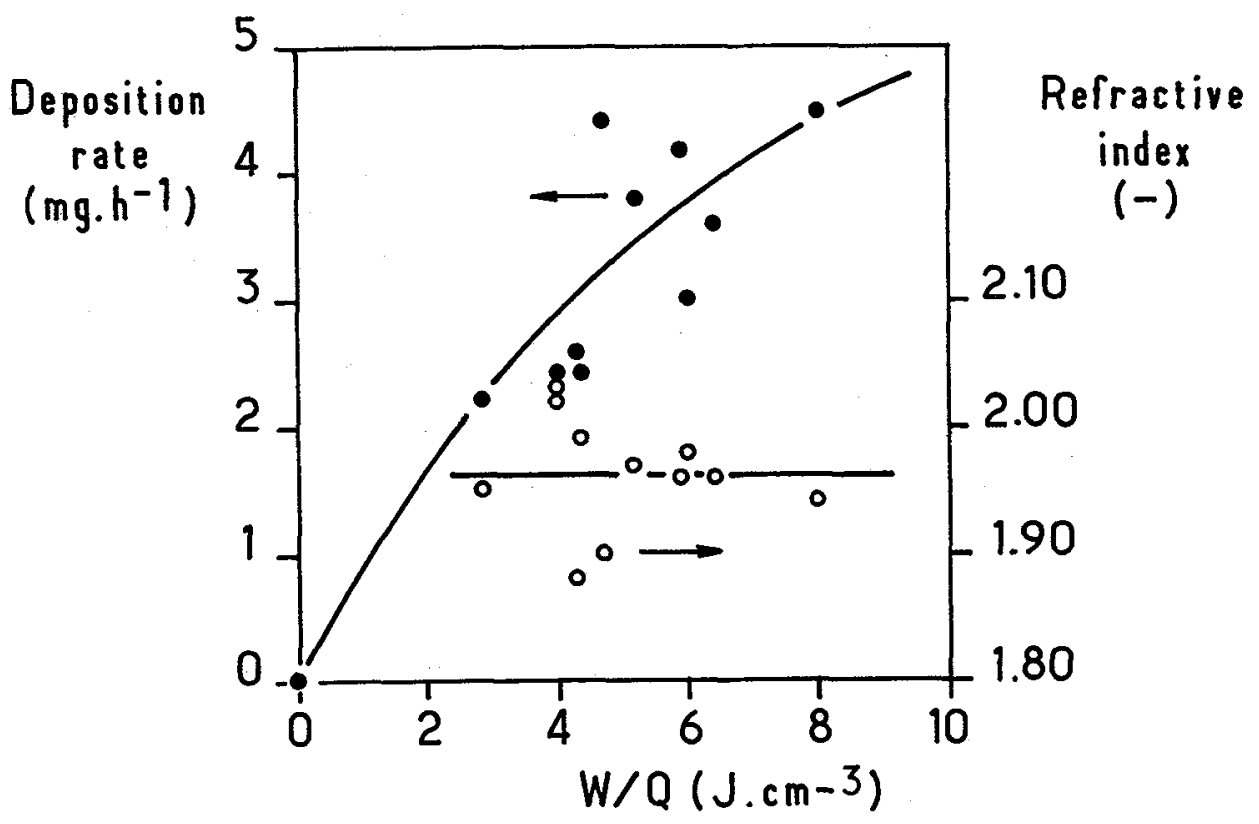

Fig.7.- Deposition rate and refractive index of the films as a function of the dissipated energy per volume unit of flowing gas ( values calculated from Figures 4 and 6 . 


\subsection{Films composition}

AUGER spectroscopy shows the characteristic peaks of $\mathrm{N}$ and $\mathrm{Si}$ plus very small amounts of oxygen and carbon. The infrared transmission spectrum between 4000 and $400 \mathrm{~cm}^{-1}$ presents a broad absorption peak with a maximum at $824 \mathrm{~cm}^{-1}$ due to $\mathrm{Si-N}$ bonds $/ 5 /$. No oxygen, carbon and hydrogen related signals were observed. Finally, using transmission electronic microscopy, the $\mathrm{Si} / \mathrm{N}$ ratio /15/ was measured. As an example, Figure 8 shows the spectrum of a silicon nitride film having a refractive index of 1.96 : the $\mathrm{Si} / \mathrm{N}$ ratio was 0.754 .

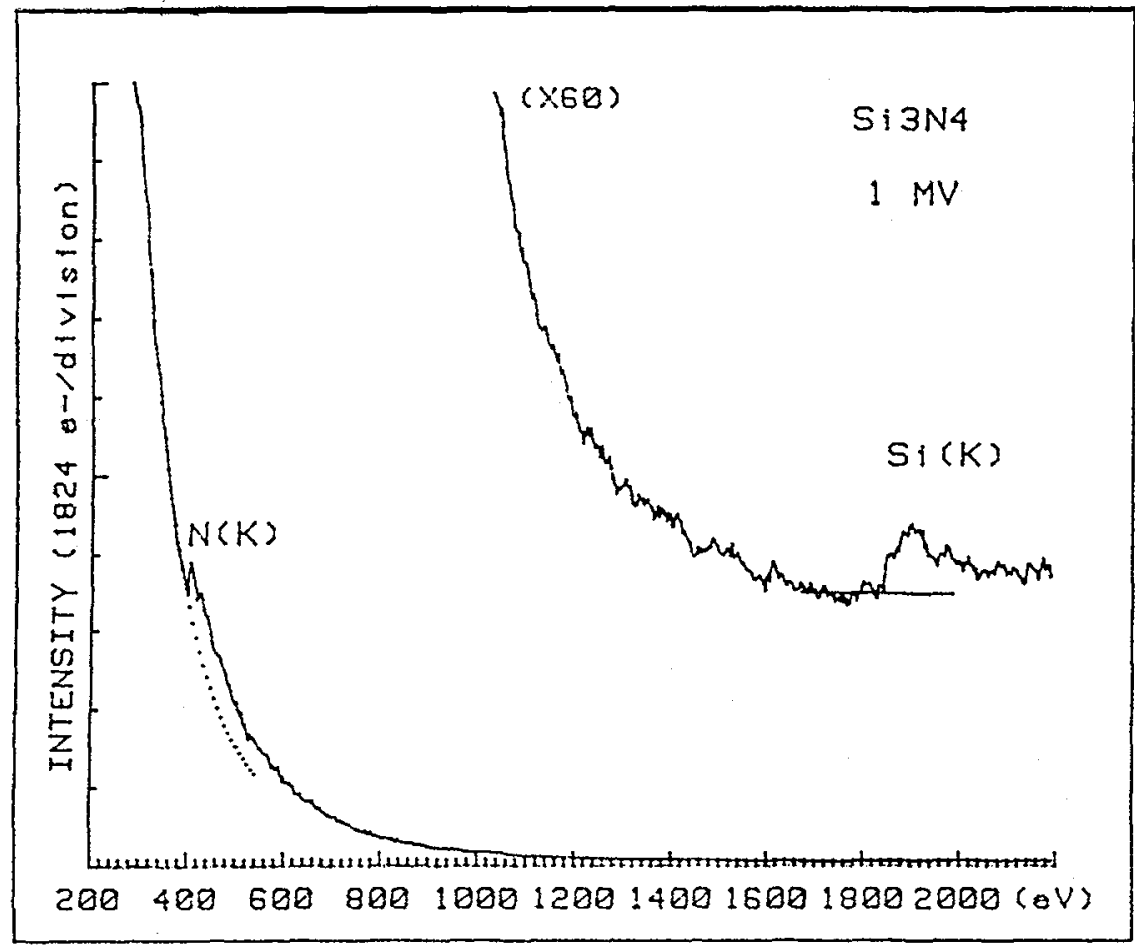

Fig.8.- Electron energy loss spectrum by transmission electronic microscopy of a 1.96 refractive index silicon nitride film. The calculated Si/N ratio was 0.754 .

\section{4-CONCLUSION}

Silicon nitride films have been deposited on heated silicon substrates $\left(800^{\circ} \mathrm{C}\right)$ from $\mathrm{Si}\left(\mathrm{CH}_{3}\right)_{4}-\mathrm{NH}_{3}-\mathrm{H}_{2}$ mixtures activated at room temperature by an a.c. discharge at low frequency $(400-600 \mathrm{~Hz})$. The conditions for deposition of high quality silicon nitride films were studied.

\section{ACKNOWLEDGEMENTS}

The authors wish to thank Mrs. T. Bouyssou (UPS), Drs. J.Sevely (LOE), E. Scheid (LAAS) and R. Berjoan (IMP) for their help respectively in IR, TEM, Ellipsometry and AUGER studies. 


\section{5-REFERENCES}

/1/ JENSEN K.F, Chem. Eng. Sci.,42, (1987) 923.

/2/ BLAAUW C., J. Electrochem. SOc., 131, (1984) 1114.

/3/ CLAASSEN W.A.P., VALKENBUR W.G.J.N.,WILLEMSEN M.F.C., and WIJGERT W.M.V.D., J. Electrochem. SOC., 132, (1985) 893.

/4/ SADHIR R.K., SAUNDERS H.E., and BENNETT A.I., J. Appl. Polymer Sci., Appl. Polymer Symp., 46 (1990) 209.

/5/ SHIMOZUMA M., KITAMORI K., OHNO H., HASEGAWA H. and TAGASHIRA H., J. Electron. Mat., 14 (1985) 573.

/6/ ROELS N., LECOINTE T., GUINEBRETIERE R. and DESMAISON J., J. de Physique, Colloque C 5, (1989) 50 , 435.

/7/ SHERMAN A., Thin Solid Films, 113 (1984) 135.

/8/ BES R.S., and OLIVARES FUENTES A., Entropie, 102 (1981) 3.

/9/ MANLEY T.C., Trans. Electrochem. SOC., 84 (1943) 83.

/10/ ARMAS B., BES R.S., COMBESCURE C., DARTIGUES G. and THENEGAL D. , French patent, $\mathrm{N}^{\circ} 88.17369,22$ Dec. 1988 ; European patent $\mathrm{N}^{\circ}$ $89.203219 .4,18$ Dec. 1989.

/11/ LUNT R.W., Ph. D. Thesis, London, (1936); EMELEUS K.G. and LUNT R.W., Trans. Faraday Soc., 32 (1936); see also LUNT R.W., Advan. Chem. Ser., 21 (1959) 286 and 80 (1969) 452 .

/12/ BES R.S., ROUTIE R.J, and COSTE C., Ozone Sci. and Eng., 7 (1985) 299.

/13/ DUN H., PAN P., WHITE F.R. and DOUSE R.W., J. Electrochem. SOC., 128 (1981) 1555.

/14/ Von ENGEL A., Ionized Gases, $S^{\text {nd }}$. Ed., Oxford University Press (1965).

/15/ KIHN Y., Thèse d'Etat, Université Paul Sabatier, Toulouse, (1985) 